\title{
SIKAP NASIONALISME MAHASISWA UNIVERSITAS COKROAMINOTO YOGYAKARTA TAHUN AKADEMIK 2015-2016
}

\author{
Heri Kurnia \\ Pendidikan Pancasila dan Kewarganegaraan Universitas Cokroaminoto Yogyakarta \\ Jl. Perintis Kemerdekaan, Gambiran, Pandeyan, Umbulharjo, Kota Yogyakarta 55161 \\ Email: herikurnia@ucy.ac.id
}

\begin{abstract}
ABSTRAK
Penelitian ini bertujuan menjawab permasalahan tentang sikap nasionalisme mahasiswa Universitas Cokroaminoto Yogyakarta Tahun Akademik 2015-2016. Metode penelitian yang digunakan dalam penelitian ini meliputi pendekatan diskriptif, tepatnya variabel penelitian sikap nasionalisme mahasiswa Universitas Cokroaminoto Yogyakarta, penelitian ini adalah penelitian sampel yaitu dengan menggunakan metode purposive sample atau sampel bertujuan. Teknik pengumpulan data menggunakan kuesioner dan dokumentasi, metode analisa data menggunakan metode analisis diskriptif dengan teknik persentase.

Hasil penelitian menunjukkan sikap nasionalisme mahasiswa tinggi dan positif, dengan rata-rata persentase $73 \%$, adapun indikator-indikator untuk mengukur sikap nasionalisme adalah pengetahuan tentang cinta tanah air, kemandirian, multikulturalisme, perasaan cinta tanah air, kemauan untuk cinta tanah air, kemandirian dan multikulturalisme.
\end{abstract}

Kata Kunci: Sikap nasionalisme, mahasiswa, Universitas Cokroaminoto Yogyakarta

\section{PENDAHULUAN}

Pada era globalisasi, pergaulan antar manusia, antar bangsa, etnik, suku, ras, agarna, antar budaya, semakin dekat, menyempit, kemajuan iptek yang sangat pesat, khususnya teknologi informasi dan komunikasi serta transportasi, pasar bebas serta ketatnya persaingan antar bangsa, sehingga nyaris tidak ada jarak antar negara dari sisi ruang dan waktu. Setiap bangsa untuk dapat bersaing di kancah global mutlak perlu kemandirian, kemampuan daya saing dan penguasaan iptek. Era globalisasi pada dasarnya era persaingan sumber daya manusia, untuk itu keahlian dan keterampilan sumberdaya manusia diyakini sebagai kunci untuk memenangkan persaingan dan penguasaan iptek dan memperjuangkan kepentingan nasional, sumberdaya manusia yang handal tersebut diperlukan bagi kemajuan dan eksistensi bangsa dan negara di era global sebagai perwujudan dari rasa nasionalisme, Bangsa yang menjunjung tinggi nasionalisme manakala individu dan masyarakat memiliki komitmen yang tinggi, kesetiaan, memiliki jati diri, kemandirian, dan bangga sebagai bangsa Indonesia. Termasuk di dalamnya dalam mengakses iptek tidak terlepas dari jati diri bangsa yang memiliki karakteristik adat istiadat, budaya, sistem nilai serta Ideologi bangsa Indonesia yaitu Pancasila. Empat pilar bangsa Indonesia Pancasila, UUD 1945, Bhinneka Tunggal Ika, dan NKRI tetap terjaga. 
Namun demikian perlu kerja keras untuk inewujudkan tujuan dan cita-cita tersebut, dampak derasnya arus globalisasi dengan semakin tidak terbendungnya masuknya teknologi informasi, transportasi, dan komunikasi serta ideologi, budaya, dan sistem ekonomi global dapat kita rasakan saat ini, baik dari sisi positif maupun negatif. Dampak positif diantaranya semakin efesien dan efektif dalam berbagai aspek kehidupan kita serta kemajuan dberbagai bidang kehidupan. Dampak negatif diantaranya mulai bergesernya nilai-nilai budaya lokal digeras budaya barat, krisis jati diri, serta mulai lunturnya rasa nasionalisme masyarakat khususnya generasi muda.

Fenomena globalisasi nampak dalam kehidupan sehari-hari yang melanda masyarakat, khusunya generasi muda diantaranya melalui makanan (food), pakaian/mode (fashion), dan hiburan (fun). Sebagian generasi muda kita menunjukkan image modern dengan pemahaman yang keliru melalui gaya hidup atau style simbol dari ketiga hal di atas. Adanya kontroversi di kalangan masyarakat karena adanya benturan nilai-nilai budaya dan agama. Nilai-nilai lokal budaya bangsa gotong royong, guyub, rukun, teposliro, mulai terkikis arus nilai-nilai budaya barat seperti kebebasan, individualisme, konsumerisme.

Ary Ginanjar Agustian (2008) bahwa krisis multidimensi yang dialami bangsa Indonesia saat ini bermuara pada krisis moralitas, yaitu hilangnya kejujuran, hilangnya rasa tanggungjawab, tidak visioner, rendahnya disiplin, krisis kerjasama, krisis keadilan, dan kepedulian. Krisis moralitas berdampak pada krisis nasionalisme, seperti korupsi, mulai lunturnya nilai-nilai kejuangan, mulai pudarnya semangat kerja keras, bangga memakai produk dan budaya dari luar negeri, lunturnya kesatuan.

Reformasi semula diharapkan dapat mengembalikan degradasi moral dan krisis rasa nasionalisme, mampu meningkatkan kesejahteraan serta keadiian masyarakat. Namun lebih dari sepuluh tahun reformasi ternyata dalam berbagai bidang kehidupan kondisinya tidak lebih menggembirakan. Menurut Komarudin Hidayat (2008) belajar dari berbagai negara yang tergolong maju, setidaknya ada pelajaran penting yang harus menjadi pelajaran bagi bangsa Indonesia yaitu haras menciptakan pemerintahan yang bersih dan pendidikan yang bagus.

Pendidikan sebagai wahana strategis bagi pembentukan rasa nasionalisme, khususnya bagi generasi muda sebagai generasi penerus calon pemimpin bangsa Indonesia yang akan datang. Untuk itu kaum muda perlu dipersiapkan untuk memegang estafet kepemimpinan bangsa dalam meraih cita-cita dan tujuan bangsa yang luhur. Generasi muda perlu dipersiapkan sebagai sumber daya manusia yang handal sebagai manusia yang bertaqwa dan beriman, cerdas, terampil, berbudi pekerti luhur, berkepribadian yang tangguh, menguasai iptek, memiliki kepedulian terhadap lingkungan, dan berjiwa sosial, dan kebanggaan terhadap bangsanya. Tidak 
mudah untuk mempersiapkan sumberdaya yang handal, oleh karena memerlukan suatu proses yang lama sejak dini hingga tercapai kedewasaan dan ken andirian. Proses pendidikan yang dimulai dari dalam lingkungan keluarga sebagai fondasi penanaman nilai-nilai, dilanjutkan pendidikan sekolah yang memberikan bekal ilmu pengetahuan dan teknologi, serta pendidikan dalam masyarakat. Pendidikan berlangsung dalam ketiga lembaga pendidikan tersebut termasuk pendidikan nasionalisme. Pendidikan formal sekolah menanamkan nasionalisme sejak dini pada pendidikan anak usia dini berlanjut ke sekolah dasar, sekolah menengah dan pendidikan nasionalisme terdapat dalam kurikulum perguruan tinggi, meskipun pendidikan nasionalisme ditanamkan sejak dini namun belum menjamin kuatnya nasionalisme dikalangan generasi muda, hal ini dapat kita lihat berbagai permasalahan bangsa kita saat ini. Diantaranya berkembangnya faham kebebasan, bangga terhadap produk luar dan kurangnya kebanggaan terhadap budaya dan tradisi lokal, orientasi gaya hidup barat, mulai memudarnya nilai-nilai budaya lokal.

Dari latar belakang masalah di atas, dapat diidentifikasi permasalahan sebagai berikut: (1). Globalisasi dengan kemajuan iptek, yaitu media elektronik dan media cetak, mahasiswa banyak mengakses teknologi yang dapat berdampak pada rasa nasionalisme mahasiswa, apakah akses teknologi dapat mempengaruhi sikap nasioanlisme mahasiswa?; (2). Faktor dominan apa antara media elektronik dan media cetak yang mempengaruhi rasa nasionalisme mahasiswa?; (3). Pendidikan berlangsung dalam keluarga, sekolah dan masyarakat, dari ketiga lembaga pendidikan tersebut lembaga pendidikan mana yang dominan menanamkan rasa nasionalisme ?. Sebagai dampak global; (4). Mahasiswa sebagai kaum muda identik dengan mode, gaya hidup, dan simbol modern, dimana hal ini kadang berbenturan dengan nilai budaya lokal, Apakah budaya barat dapat mempengaruhi sikap nasionalime mahasiswa?; (5) Mahasiswa memperoleh pendidikan nasionalisme sejak dini dalam keluarga, sekolah dasar dan menengah sampai di jenjang pendidikan tinggi, seharusnya mahasiswa memiliki pengetahuan dan pemahaman serta sikap yang bagus terhadap nasioanlisme, bagaimanakah sikap nasionalime mahasiswa, dalam penelitian ini mahasiswa Universitas Cokroaminoto Yogyakarta.

Untuk itu perlu upaya-upaya yang lebih keras lagi untuk memupuk jiwa nasionalisme di kalangan generasi muda kita. Penelitian tentang seberapa jauh sikap nasionalisme mahasiswa Universitas Cokroaminoto Yogyakarta menarik untuk dilakukan, sebagai bahan kajian dan masukan guna mendapatkan alternatif metode dan strategi dalam pembelajaran pendidikan nasionalisme kepada generasi muda. 


\section{KAJIAN TEORI}

Banyak pendapat tentang definisi dan makna nasioanalisme, diantaranya pengertian nasionalisme menurut ensiklopedia Indonesia: "Nasionalisme adalah paham kebangsaan yang tumbuh karena persamaan nasib, serta kepentingan untuk hidup bersama sebagai suatu bangsa yang merdeka" (1991:31). Zamroni yang dikutip Cholisin: nasionalisme menunjukkan kepada bangsa "bangga menjadi orang Indonesia, berani berkorban untuk membela bangsa dan negara, dan mendahulukan kepentingan nasional daripada kepentingan golongan" (1997:72) Nasionalisme sebagai suatu gerakan ideologis berkaitan dengan otonomi, kesatuan dan identitas nasional, hal ini sejalan dengan pendapat Sartono Kartodiharjo (1993:16) bahwa "nasionalisme sebagai ideologi perlu menjiwai setiap warga negara yang wajib secara moral (moral commitment) dengan loyalitas penuh mengabdikan diri kepada kepentingan Negara" selanjutnya dikatakan bahwa untuk membentuk nasionalisme dalam proses sejarah menunjukkan variasi yang pada hakekatnya memuat beberapa prinsip, yaitu: kesatuan (unity), kebebasan (liberty); kesamaan (equality); kepribadian; prestasi (performance) (1993:43).

Dalam pengertian nasionalisme tersebut mengandung makna bahwa hubungan antara warganegara dengan negara dan hubungan antar manusia sebagai makhluk sosial yang dilandasi nilai-nilai luhur tersebut. Hubungan antara warganegara dengan negara yang dilandasi rasa cinta tanah air, kesetiaan, dan kerelaan berkorban untuk bangsa dan negara, dan hubungan manusia dengan manusia lain sebagai makhluk sosial yang dilandasi kesamaan derajat tidak ada diskriminasi sesuai dengan ciri masyarakat madani dan masyarakat yang berperadaban yang menjunjung tinggi nilai-nilai kemanusiaan. Namun demikian tidak mudah bagi bangsa Indonesia yang memiliki karakteristik yang unik sebagai negara kepulauan terbesar di dunia, dengan beragam suku, budaya, bahasa, dan adat istiadat sera agama yang bermacam-macam, keberagaman tersebut disatu sisi sebagai anugrah kekayaan bangsa Indonesia namun juga di sisi lain sebagai salah satu sumber konflik, sehingga bangsa Indonesia rawan terjadi konflik. Untuk itu perlu komitmen setiap warganegara Indonesia untuk memupuk kesatuan, persamaan nasib, toleransi, kerelaan berkorban tanpa membedakan keturunan, warna kulit, ras, suku, budaya. Seperti yang tercantum dalam ensiklopedi Kebudayaan Nasional Indonesia (1990) unsur nasionalisme dapat terdiri dari persamaan darah, keturunan (ras), suku bangsa, daerah tempat tinggal, bahasa dan kebudayaan.

Istilah nasionalisme mengandung makna: (1) suatu proses pembentukan atau pertumbuhan bangsa-bangsa, yaitu proses pembentukan bangsa-bangsa, proses itu sendiri acapkali membentuk nasionalisme; (2) suatu kesadaran memiliki bangsa; (3) bahasa dan simbolisme 
nasioanalisme layak mendapat perhatian lebih; (4) suatu gerakan sosial dan politik demi bangsa bersangkutan; (5) suatu doktrin atau ideologi bangsa. (Frans Likaja: 1987).

Nasionalisme suatu kesadaran ideologi dan gerakan yang kuat dalam berbangsa, kehidupan berbangsa. Kaelan (2004:129) mengungkapkan prinsip-prinsip nasionalisme Indonesia yang berdasarkan Pancasila adalah bersiafat majemuk tunggal, adapun unsur-unsur yang yang membentuk nasionalisme (bangsa Indonesia adalah (1) kesamaan sejarah; (2) kesatuan nasib; (3) kesatuan kebudayaan; (4) kesatuan wilayah; (5) kesatuan asas kerokhanian.

Indonesia sebagai bagian dari dunia global, perlu menjaga identitasnya dengan membangun Indonesia yang multikultural, hal ini dapat terwujud apabila ada keinginan dari seluruh komponen masyarakat untuk menjadikannya sebagai pedoman. Nasionalisme dalam penelitian ini adalah semangat kebangsaan, kesatuan, kecintaan, kemandirian, penguasaan iptek, menjaga kebudayaan dan kesadaran multikulturalisme untuk mewujudkan Indonesia yang kuat sejajar dengan negara maju lainnya sebagai bagian dari masyarakat global.

Sikap diartikan derajat atau tingkat kesesuaian seseorang terhadap obyek tertentu. Keserasian atau tingkat dinyatakan dalam skala. Azwar inengemukakan bahwa pengungkapan sikap akan mengklasifikasikan respons evaluatif seseorang pada posisi menyenangkan atau tidak menyenangkan, pada posisi setuju atau tidak setuju. (Azwar, 1988:12). Sikap berhubungan dengan pengetahuan dari perasaan terhadap obyek, sikap berkaitan dengan kecenderungan seseorang berperilaku.

Sikap adalah kecenderungan seseorang untuk bertindak atau bereaksi. Tindakan tersebut dapat berwujud menolak atau menerima suatu obyek ataupun kegiatan-kegiatan sosial. Hal ini dipengaruhi oleh nilai-nilai yang dianut, pemikir, pengetahuan, dan keyakinan. Sikap merupakan salah satu aspek psikologis individu yang sangat penting karena sikap merupakan kecenderungan untuk berperilaku sehingga akan banyak mewarnai perilaku seseorang.

Sikap nasionalisme adalah pengetahuan, perasaan, dan kecenderungan perilaku kebangsaan, kesatuan, kecintaan, kemandirian, penguasaan iptek, menjaga kebudayaan dan kesadaran multikulturalisme untuk mewujudkan Indonesia yang kuat sejajar dengan negara maju lainnya sebagat bagian dari masyarakat global.

Penelitian ini adalah penelitian diskriptif, menurut Hadari Nawawi (2005:63) metode diskriptif dapat diartikan sebagai prosedur pemecahan masalah yang diselidiki dengan menggambarkan/melukiskan keadaan subyek/obyek penelitian (seseorang, lembaga, masyarakat, dan lain-lain) pada saat sekarang berdasarkan fakta-fakta yang tampak atau sebagaimana adanya. 
Selanjutnya Suharsimi Arikunto (2000:309) mengemukakan penelitian diskriptif merupakan penelitian yang dimaksudkan untuk mengumpulkan informasi mengenai status suatu gejala yang ada, yaitu keadaan gejala menurut apa adanya pada saat penelitian dilakukan, dalam penelitian diskriptif tidak dimaksudkan untuk menguji hipotesis tertentu, tetapi hanya menggambarkan apa adanya tentang sesuatu variabel, gejala, atau keadaan.

Dalam penelitian diskriptif ini peneliti tidak melakukan pengujian hipotesis, melainkan mengemukakan gejala-gejala apa adanya. Lebih lanjut Suharsimi Arikunto (1992:206) mengemukakan pada umumnya penelitian deskriptif merupakan penelitian non hipotesis sehingga dalam langkah penelitian tidak perlu merumuskan hipotesis.

Popuiasi dalam penelitian ini adalah mahasiswa Universitas Cokroaminoto Yogyakarta Tahun Akademik 2009-2010, namun demikian peneliti tidak melakukan penelitian populasi melainkan penelitian secara sampel.

Kartini Kartono (1996:129) mengartikan sampel adalah contoh, monster, representasi atau wakil dari satu populasi yang cukup besar jumlahnya, yaitu satu bagian dari keseluruhan yang dipilih, dan representatif sifatnya dari keseluruhannya. Pendapat di atas diperkuat oleh Suharsimi Arikunto yang mengartikan sampel sebagian atau wakil populasi yang diteliti, dinamakan penelitian sampel apabila kita bermaksud untuk menggeneralisasikan hasil penelitian sampel, yang dimaksud meggeneralisasikan adalah mengangkat kesimpulan sebagai sesuatu yang berlaku bagi populasi. (1992:104).

Jenis sampel dalam peneltian ini adalah sampel bertujuan (purposive sample), menurut Kartini Kartono (1996:148) sampel bertujuan adalah dalam memilih subyek-subyek sampelnya, diambil anggota-anggota sampel sedemikian rupa sehingga sampel tersebut benar-benar mencerminkan ciri-ciri dari populasi yang sudah dikenal sebelumnya. Suharsimi Arikunto (1990:128) mendifinisikan sampel bertujuan (purposive sample) yaitu teknik sampling yang digunakan oleh peneliti jika peneliti mempunyai pertimbangan-pertimbangan tertentu di dalam pengambilan sampelnya.

Teknik sampel bertujuan yang dimaksud adalah mahasiswa semester ganjil tahun akademik 2015-2016 yang menempuh mata kuliah pendidikan kewarganegaraan, Prodi Pendidikan Pancasila dan Kewarganegaraan, Ilmu Hukum, Prodi Akuntansi, Prodi Manajemen, Prodi Pendidikan agama Islam, Prodi PGMI, dan Prodi Ahwal Alsykhsiyah yang berjumlah 58 mahasiswa.

Pengumpulan data sikap nasionalisme mahasiswa dilakukan dengan teknik pengumpulan data berupa kuesioner/angket, sedangkan data mahasiswa yang dijadikan sebagai responden menggunakan dokumentasi. Kuesioner adalah sejumlah sejumlah pertanyaan atau pernyataan 
tertulis yang digunakan untuk memperoleh informasi dari responden dalam laporan tentang pribadinya atau hal-hal yang ia ketahui.

Kuesioner yang digunakan adalah kuesioner tertutup dengan pilihan jawaban untuk mengukur sikap nasioanlisme dengan skala sikap dari Likert, untuk pertanyaan atau pernyataan positif dengan skor Setuju: 3; Ragu-ragu: 2; Tidak setuju untuk pernyataan negatif dengan skor: Setuju: 1; Ragu-ragu: 2; Tidak setuju: 3.

Sikap adalah kesiapan dan kesediaan seseorang untuk menerima atau menolak suatu obyek berdasarkan penilaian terhadap obyek itu, apakah berarti atau tidak baginya. Sikap berhubungan dengan pengetahuan dan perasaan seseorang berhadap obyek. Sikap juga dipandang sebagai kecenderungan seseorang untuk berperilaku, hasil belajar sikap nampak dalam bentuk kemauan dan minat. (Nana Sudjana, 1989).

Nasioanalisme adalah bangga menjadi orang Indonesia, berani berkorban untuk membela bangsa dan negara, dan mendahulukan kepentingan nasional daripada kepentingan golongam. (Zamroni dikutip Cholisin, 1997).

Nasioanlisme mengandung kemandirian, peradaban, penguasaan iptek, persatuan dan kesatuan, pertahanan dan keamanan, tempat dan kedudukan bangsa kita dalam pergaulan internasional, kemakmuran yang berkeadilan, dan keuangan negara. (Kwik Kian Gie, 2008).

Dalam penelitian ini yang dimaksud sikap nasionalisine adalah kecenderungan untuk berperilaku yang dilandasi pengetahuan, perasaan, dan kemauan terhadap, cinta tanah air, kemandirian dan multikulturalisme. Instrumen penelitian untuk angket sikap nasionalisme sebagai berikut:

Tabel 1. Kisi-kisi Sikap Nasionalisme

\begin{tabular}{|c|c|c|c|}
\hline \multicolumn{1}{|c|}{ Variabel } & Sub Variabel & \multicolumn{1}{c|}{ Indikator } & $\begin{array}{c}\text { Item } \\
\text { Pertanyaan }\end{array}$ \\
\hline \multirow{4}{*}{ Sikap Nasionalisme } & \multirow{3}{*}{ a. Pengetahuan } & a. Cinta tanah air & $2,5,8$ \\
& & b. Kemandirian & 13,15 \\
& b. Perasaan & Cinta tanah air & $1,7,17$ \\
\cline { 2 - 5 } & \multirow{2}{*}{ c. Kemauan } & a. Cinta tanah air & $6,9,10$ \\
& & b. Kemandirian & 11,14 \\
& & c. Multikulturalisme & 3,4 \\
\hline
\end{tabular}

Dokumentasi dalam penelitian ini untuk mengumpulkan data tentang mahasiswa semester 1 Prodi Pendidikan Pancasila dan Kewarganegaraan (PPKn), Prodi Akuntansi, Prodi 
Manajemen, Prodi Ilmu Hukum, Prodi Pendidikan Agama Islam (PAI) dan Prodi Ahwal Alsyakhsyiah.

Validitas penelitian digunakan untuk memperoleh keabsahan data, sehingga memperoleh derajat kepercayaan yang tinggi. Instrumen pengumpul data berupa kuesioner uiberlakukan validiatas isi, yaitu kuesioner disusun atas dasar pemikiran logis dari sikap nasionalisme yang terdiri dari indikator-indikator yang dijabarkan dalam item-item pertanyaan.

Analisis data uutuk menjawab permasalahan seberapa jauh sikap nasionalisme mahasiswa seperti yang diajukan dalam penelitian menggunakan teknik analisis data diskriptif dengan teknik persentase.

Subarsimi Arikunto (1992:206) mengemakakan data yang bersifat kuantitatif berujud angka-angka hasil perhitungan atau pengukuran dapat diproses dengan cara dijumlahkan, dibandingkan dengan jumlah yang diharapkan dan diperoleh persentase. Kadang-kadang pencarian persentase dimaksudkan untuk mengetahui status sesuatu yang dipresentasekan dan disajikan tetap berupa persentase, tetapi kadang-kadang sesudah sampai ke persentase lalu ditafsirkan dengan kalimat yang bersifat kualitatif, misalnya baik (76\%-100\%), cukup (56\%$75 \%$ ), kurang baik (40\%-55\%), tidak baik (kurang dari 40\%).

Analisis data dengan teknik persentase selanjutnya diklasifikasikan dalam kategori baik, cukup, kurang baik, dan tidak baik, kemudian dilakukan interpretasi data.

\section{PEMBAHASAN}

Dari hasil olah data tentang sikap nasionalisme mahasiswa diperoleh temuan distribusi frekuensi tertinggi pada (46-48) sebanyak 19 mahasiswa (32,76\%) dan terendah pada (37-39) sebanyak 3 mahasiswa $(5,17 \%)$.

Adapun kategori sikap nasionalisme mahasiswa pada kategori tinggi, sedang, dan rendah adalah: Tinggi: > 46, sebanyak 21 mahasiswa (36,21\%); Sedang: 42-46, sebanyak 25 mahasiswa $(43,10 \%)$; Rendah < 42, sebanyak 12 mahasiswa $(20,69 \%)$.

Sikap nasionalisme mahasiswa tinggi mencapai 36,21\%, sikap nasionalisme sedang $43,10 \%$, dan nasionalisme rendah $20,69 \%$.

Dari hasil olah data ditemukan bahwa mahasiswa memiliki pengetahuan, perasaan, dan kemauan tentang cinta tanah air, kemandirian, dan multikulturalisme yang cukup memadai. Hal ini ditunjukkan dengan tingginya persentase dari jawaban-jawaban atas pernyataan yang diajukan, tingginya pengetahuan mahasiswa dapat disebabkan oleh berbagai faktor, inenurut peneiiti diantaranya mahasiswa memperoleh pendidikan nasionalisme yang ada dalarn mata pelajaran pendidikan pancasila dan kewarganegaraan sejak di bangku pendidikan dasar sampai 
perguruan tinggi, lamanya pendidikan yang diperoleh ini juga berarti pengetahuan tersebut diperoleh secara terus menerus berkesinambungan dan selanjutnya proses penghayatan dan internalisasi secara kontinue terjadi sehingga tertanairi dalam din mahasiswa sebagai bagian dari kepribadiannya, maka perasaan cinta tanah air juga menunjukkan pada tingkat yang tinggi, perasaan ini justru semakin positif manakala ada pihak lain yang mengusik tentang harkat dan martabat bangsa, emosi sebagai kaum muda akan mudah bangkit apabila berkaitan dengan pertnasalahan permasalahan yang berkaitan dengan hajat hidup orang banyak dan jati diri bangsa. Pengetahuan yang memadai dan wawasan yang luas tentang nasionalisme menjadi dasar perasaan cinta, bangga, kerelaan berkorban untuk bangsa dan negara, kemandirian, dan juga wawasan tentang multikulturalisme. Pengetahuan dan perasaan ini sebagai dasar adanya kemauan atau keinginan yang kuat untuk berperilaku yang dilandasi oleh cinta tanah air, dalam kaitannya sebagai warganegara yang memiliki hak dan kewajiban sebagai warganegara sebagaimana dimuat dalam UUD 1945, indikator sikap nasionalisme juga ditunjukkan dari kuatnya keinginan dari kaum muda untuk mandiri, berdiri di atas kaki sendiri tidak tergantung pada bangsa dan negara lain serta percaya pada kemarnpuan sendiri dan mencintai prodnk dalam negeri. Kemandirian adalah dambaan dari mahasiswa sebagai wujud dari kepedulian sebagai warganegara Indonesia, dan sikap nasionalisme juga ditunjukkan dengan pengetahuan mahasiswa tentang multikulturalisme dan kecenderungan perilaku yang dilandasi multikulturalisme, yakni menghargai keberagaman dan perbedaan suku, ras, agama, dan adat istiadat serta nilai-nilai budaya, dengan sikap toleransi, penghargaan, dan menerima perbedaan sebagai warna dan kekayaan bangsa Indonesia.

Hasil penelitian menunjuk bahwa mahasiswa UCY memiliki sikap nasionalisme yang cukup tinggi dan positif dilihat dari hasil persentase.

\section{KESIMPULAN}

Jawaban dari pertanyaan dalam penelitian ini dapat disimpulkan bahwa sikap nasionalisme mahasiswa cukup baik, hal ini ditunjukkan sikap nasionalisme pada kategori tinggi sebanyak 21 mahasiswa (36,21\%), kategori sedang sebanyak 25 mahasiswa (43,10\%). Sikap nasionalisme mahasiswa dengan indikator pengetahuan yang berkaitan dengan cinta tanah air, kemandirian, dan multikulturalisme; perasaan cinta tanah air, dan kemauan untuk cinta tanah air, kemandirian, dan multikulturalisme. 


\section{DAFTAR PUSTAKA}

Ary GinanjarAgustia, 2008, Pembentukan Habit Menerapkan Nilai-Nilai Religius, Sosial, dan Akademik, Makalah disampaikan dalam seminar dan lokakarya pendidikan karakter, UNY.

Bimo. Walgito, Psikologi Suatu Pengantar, Yogyakarta: Fakultas Psikologi UGM.

Gerungan, 1998, Psikologi Sosial, Bandung: Eresco.

Hadari Nawawi, 2005, Metode Penelitiah Sosial, Gadjah Mada University Press.

Kaelan, 2004, Pendidikan Pancasila, Yogyakarta: Paradigma.

Kartini Kartono, 1996, Pengantar Metodologi Riset Sosial, Bandung: Mandar Maju.

Komarudin Hidayat, 2006, Pendidikan Kewarganegaraan, UIN Syarif Hidayatullah, Jakarta.

Kwik Kian Gie, 2008, Dengan Berpedoman Pada Jati Diri Bangsa dan Kepemimpinan yang Bernurani, Kita Wujudkan Cita-cita Kemerdekaan Indonersia, Makalah disampaikan dalam Sarasehan Kebangsaan Majelis Luhur Persatuan Tamansiswa dan Universitas Sarjanawiyata Tamansiswa.

Mohamad Ali, 7004, Psikologi Remaja, Jakarta, Bumi Aksara.

Naryadi, 1997, Politik dan Strategi Pertahanan Keamanan Nasional, Lemhanas, Jakarta.

Nana Sudjana, 1989, Dasar-Dasar Proses Belajar Mengajar, Bandung: Sinar Baru.

Noor Ms. Bakry, 1996, Pendidikan Kewiraan, Yogyakarta: Liberty.

Nasution, 1994, Teknologi Pengajaran, Jakrta: Bina Aksara.

Sartono Kartidiharjo, http/fisip.unmul.ac.id/dat/artic.les/nasinalism.html.

Suharsimi Arikunto, 2000, Prosedur Penelitian, Jakarta: Melton Putra. 